\title{
Influence of the chemical structure of rapeseed oil-based polyols on selected properties of polyurethane foams*)
}

\author{
Katarzyna Uram ${ }^{1)}$, Aleksander Prociak ${ }^{1), * *)}$, Maria Kurańska ${ }^{1)}$ \\ DOI: dx.doi.org/10.14314/polimery.2020.10.5
}

\begin{abstract}
In this work, we report on obtaining rigid polyurethane foams with biopolyols based on rapeseed oil. The biopolyols with different functionality were synthesized in a two-stage reaction of oil epoxidation and oxirane ring opening with 1-hexanol (P_1Hex) and 1,6-hexanediol (P_1.6Hex) and their properties were characterized (Table 2, Figs. 1-3). Next, they were used to replace petrochemical polyols in foams by up to $60 \%$ by mass (Table 1 ). The introduction of the biopolyols into the polyurethane systems affected their reactivity (Fig. 4). The replacement of the petrochemical polyols with the biopolyols caused changes in the cell structure (Tables 3,4) and the physical and mechanical properties of the resultant materials (Table 5).
\end{abstract}

Keywords: biopolyol, functionality, rapeseed oil, polyurethane foams.

\section{Wpływ struktury chemicznej biopolioli z oleju rzepakowego na wybrane właściwości pianek poliuretanowych}

Streszczenie: Sztywne pianki poliuretanowe otrzymano z udziałem biopolioli z oleju rzepakowego. Biopoliole o różnej funkcyjności zsyntetyzowano w dwuetapowej reakcji epoksydacji oleju i otwarcia pierścieni oksiranowych za pomocą 1-heksanolu (P_1Hex) i 1,6-heksanodiolu (P_1.6Hex), a następnie je scharakteryzowano (tabela 2, rys. 1-3). Piankę referencyjną modyfikowano w wyniku zastąpienia poliolu petrochemicznego biopoliolami $\mathrm{w}$ ilości do $60 \%$ mas. (tabela 1). Wprowadzenie biopolioli do systemów poliuretanowych wpłynęło na zmniejszenie ich reaktywności (rys. 4). Zastąpienie poliolu petrochemicznego biopoliolami spowodowało zmiany struktury komórkowej (tabele 3 i 4) i właściwości fizyko-mechanicznych otrzymanych materiałów (tabela 5).

Słowa kluczowe: biopoliol, funkcyjność, olej rzepakowy, pianki poliuretanowe.

Polyurethanes (PURs) as polymeric materials are used in solid and porous forms. Urethane bonds are formed by the reaction of polyols with isocyanates. From the industrial point of view, PURs are very important materials that can be used in various areas of life, e.g. in architecture, the automotive industry [1, 2], furniture industry [3], as thermal insulation in construction [4], paints [5], medical devices [6] or adhesives and sealants [7].

Rigid polyurethane foams (RPUFs) are materials that combine good adhesion to various surfaces and high compressive strength with a low thermal insulation coefficient. Thus, such foams are used as thermal insulation materials for buildings and tanks [8]. These thermal insulation materials can

\footnotetext{
1) Cracow University of Technology, Department of Chemistry and Technology of Polymers, Warszawska 24, 31-155 Kraków, Poland.

*) Material contained in this article was presented at the Science and Technology Conference on "Polyurethanes 2019", Ustroń, Poland, 13-16 October 2019.

**) Author for correspondence: aleksander.prociak@pk.edu.pl
}

work effectively in a wide temperature range from $-235^{\circ} \mathrm{C}$ to $+150^{\circ} \mathrm{C}$ [9]. In addition, RPUFs with a closedcell structure are used as cores in layered composites for packaging and cushioning [10].

Currently, both basic components of PUR systems (polyols and isocyanates) are synthesized on an industrial scale mainly from petrochemical sources $[1,11]$. Concerns related to environmental problems associated with the use of petroleum-based PURs have encouraged scientists to focus on replacing all or part of petroleum polyols in RPUFs with polyols from renewable resources [6]. The life cycle assessment of vegetable oil-based polyols has shown that such ingredients have a very good environmental impact when used in the preparation of, e.g. PUR foams [11, 12].

Nowadays, petrochemical components are partly replaced by various derivatives of renewable raw materials. Among them, vegetable oils can be used as a source for the production of biopolyols. Chemically, vegetable oils are esters of glycerol and higher fatty acids. Depending on the geographical area, different oils are used to produce biopolyols. In North and South America 
mainly soybean oil is used, in Asia - palm and coconut oil. In Europe, rapeseed and sunflower oils are potential raw materials for the production of biopolyols $[4,7,13,14]$. These sources are readily available and biopolyols are environmentally friendly [15].

Most vegetable oils do not have in their chemical structures functional groups that are capable of reacting with isocyanates. Therefore, their chemical modification is necessary for use in PUR systems [12, 13, 16]. Biopolyols from vegetable oils can be obtained by modifying ester groups or unsaturated bonds in fatty acid chains. The reactions focused on ester groups are transesterification or transamidization, while it is possible to modify double bonds in hydroformylation or ozonolysis, followed by hydrogenation, as well as a two-stage method: epoxidation and oxirane ring opening $[4,6,16,17]$. The last method mentioned above involves oxidation of unsaturated bonds with peracetic acid, which is formed in situ by the reaction of hydrogen peroxide and acetic acid. As a result of this reaction, epoxy rings are formed. In the second stage, the oxirane rings are opened by various oxirane ring-opening agents. There are application examples of oxirane openers, such as amines, alcohols, carboxylic acids and halogenated acids $[6,18]$.

The type of agent used in the ring-opening reaction affects the functionality of biopolyols [5]. The biopolyols thus obtained may contain primary or secondary hydroxyl groups or both. The content of these groups has an impact on the PUR cross-linking density and final properties of foamed materials, e.g. higher compressive strength [6, 19]. However, dangling chains derived from saturated fatty acids that are part of hydrocarbon chains have a plasticizing effect that reduces PUR stiffness [8].

The method of obtaining biopolyols has a significant impact on their characteristics, including the molecular weight, acid number, hydroxyl number and functionality. The functionality of a biopolyol is associated with the content of double bonds in oil [20], as well as the type and conditions of modification [5]. In general, the basic properties of biopolyols described in the scientific literature are as follows: the molecular weight in the range of 500-4000 g/mol, hydroxyl values from 50 to $300 \mathrm{mgKOH} / \mathrm{g}$ [7] and functionality from 2 to 8 [21].

The two-stage method of epoxidation and opening epoxy rings leads to biopolyols with functionality in the range of 2-6 and a hydroxyl number of $50-250 \mathrm{mgKOH} / \mathrm{g}$ (average molecular weight $M n=900-1500 \mathrm{~g} / \mathrm{mol}$ ). On the other hand, transesterification reactions of ester groups allow obtaining products with a higher hydroxyl value, but with a lower $M n$ and functionality: $250-300 \mathrm{mgKOH} / \mathrm{g}$, $M n=350-450 \mathrm{~g} / \mathrm{mol}$ and $f=2.0-2.5$, respectively [22].

The method and conditions of the synthesis of biopolyols, and, consequently, their properties, affect the foaming process of PUR systems and the physical and mechanical properties of rigid foams [23]. There have been studies in which petrochemical polyols were replaced with biopolyols with different chemical structures. Kurańska et al., 2019 [17] used two biopolyols in their research: one based on lignin (LP) and the other one based on rapeseed oil (RP). Biopolyol LP was characterized by a hydroxyl number of $262 \mathrm{mgKOH} / \mathrm{g}$, while for biopolyol RP it was $264 \mathrm{mgKOH} / \mathrm{g}$. Despite similar hydroxyl values, biopolyol LP was much more reactive. It was observed that by increasing the amount of the LP and RP biopolyols in the PUR system, the apparent density of RPUFs decreased. However, the values of the thermal conductivity coefficient were similar to those achieved for the foam with petrochemical polyol only. Modification of the PUR system up to $30 \%$ by weight affected the compressive strength in parallel and perpendicular directions to the foam growth. Higher compressive strength was observed in a direction parallel to the direction of foam growth as an effect of the anisotropic cell structure of the PUR foams.

Another relationship was found in the work of Ji et al., 2015 [16]. They used three different biopolyols to prepare RPUFs. The biopolyols were obtained in a twostep method: epoxidation of soybean oil and opening oxirane rings with methanol, phenol and cyclohexanol. Modification of the polyurethane systems with such biopolyols generally resulted in deterioration of the properties of the foams obtained. As the content of the biopolyols in the PUR foam formulation increased, the apparent density of all the resultant materials also increased. The addition of the biopolyols had an effect on the cellular structure of the foams. The foams with the biopolyol containing methanol were characterized by a uniform cell shape compared to the foams obtained with the biopolyol containing phenol and cyclohexanol. On the other side, when the amount of the biopolyols with phenol and cyclohexanol was increased, smaller cells in the PUR foams were obtained. This was due to higher viscosity of the polyol premix, which hindered the formation and distribution of the cells formed by the blowing agent. Smaller cell sizes in the RPUFs modified with the biopolyol containing phenol resulted in higher compressive strength compared to the materials modified with the biopolyol containing methanol. The use of the biopolyol with cyclohexanol did not improve the foam properties. Those foams had lower compressive strength due to the plasticization effect of the aliphatic hexagonal ring and heterogeneous cell structure despite a smaller cell size.

In this study, two types of biopolyols were synthesized on a laboratory scale by epoxidation of rapeseed oil followed by oxirane ring opening. Different oxirane ring-opening agents were used: 1-hexanol and 1,6-hexanediol in order to obtain biopolyols with different functionality and type of hydroxyl group (primary, secondary). In the next step, the rapeseed oil-based biopolyols were used to modify a RPUF formulation based on petrochemical components. The effects of the type and content of the biopolyols obtained on the foaming process as well as the cell structure and physical-mechanical properties of the foams are discussed. 


\section{EXPERIMENTAL PART}

\section{Materials}

In the synthesis of the biopolyols, the following raw materials were used:

- Fresh rapeseed oil, ZT Kruszwica S.A.

- Hydrogen peroxide (30\% water solution), Chempur.

- Glacial acetic acid, Avantor Performance Materials Poland S.A.

- Amberlyst 15 ion exchange resin (catalyst), Sigma Aldrich.

The content of the catalyst used in the epoxidation reaction was $15 \mathrm{wt} \%$ with respect to the oil mass.

1-hexanol, 1,6-hexanediol used as oxirane agent, Sigma Aldrich.

Tetrafluoroboric acid - oxirane ring-opening catalyst, Sigma Aldrich.

Concentrated sulfuric acid (oxirane ring-opening catalyst), Avantor Performance Materials Poland S.A.

In the synthesis of the PUR foams, the following raw materials were used:

Petrochemical polyol - Rokopol RF-551, PCC Rokita, polyether polyol characterized by hydroxyl value $420 \mathrm{mgKOH} / \mathrm{g}$.

Polymeric methylene diphenyldiisocyanate (PMDI) containing $31 \%$ of free isocyanate groups was supplied by Minova Ekochem SA.

Polycat 218 - reactive amine catalyst providing strong urea-reaction (blowing) catalysis, Evonik Industries AG.

Niax silicone L-6195 - highly stabilizing surfactant (silicone) for slow reactivity systems, Momentive Performance Materials ${ }^{\mathrm{TM}}$.

Carbon dioxide generated during the reaction of water with diisocyanate was used as a chemical blowing agent.

\section{Synthesis of rapeseed oil-based polyols}

Biopolyols were synthesized from rapeseed oil by introducing hydroxyl groups to the unsaturated sites of its triglycerides structures. For this purpose, a two-step method of obtaining biopolyols was used: epoxidation and opening oxirane rings. The first step was epoxidation of unsaturated bonds in fatty acids. The reaction mixture consisted of fresh rapeseed oil and catalyst put into three neck-flask with mechanical stirrer and heating bowl. As a catalyst, ion exchange resin Amberlyst 15 was applied. The mixture was heated to a temperature of $50^{\circ} \mathrm{C}$. Next, acetic acid was added and the reaction mixture was stirred for half an hour. After that time, hydrogen peroxide was added and the process was carried out for $6 \mathrm{~h}$ in a temperature of $65^{\circ} \mathrm{C}$. The molar ratios of unsaturated bonds : acetic acid : hydrogen peroxide were $1: 0.35: 1.40$ and $1: 0.24: 0.96$ and allowed obtaining epoxidized oils with epoxy values $E v=0.30$ and $E v=0.21 \mathrm{~mol} / 100 \mathrm{~g}$, respectively. The epoxidized oils were washed with water and distilled under vacuum.
In the second step, opening oxirane rings by different alcohols took place. As oxirane ring-opening agents, 1-hexanol and 1,6-hexanediol were used. The first type of alcohol was applied in the reaction with the epoxidized oil of smaller $E v$ to obtain biopolyol P_1Hex while the epoxidized oil characterized by $E v=0.3 \mathrm{~mol} / 100 \mathrm{~g}$ reacted with 1,6-hexanediol to obtain biopolyol P_1.6Hex.

\section{Synthesis of $P_{-} 1$ Hex}

The epoxidized oil with $E v=0.21 \mathrm{~mol} / 100 \mathrm{~g}$ was introduced into a three-neck flask and heated to $50^{\circ} \mathrm{C}$. Next, 1-hexanol with a solution of tetrafluoroboric acid in water $(48 \%)$ was added. The amount of the catalyst was $0.45 \%$ by weight of the epoxidized oil. The reaction was carried out for 20 minutes at a temperature of $65^{\circ} \mathrm{C}$.

\section{Synthesis of $\mathbf{P} \_16 \mathrm{Hex}$}

1,6-hexanediol and sulfuric acid as a catalyst were introduced into the reactor. The amount of the catalyst was $0.3 \%$ based on the weight of the epoxidized oil. Next, the epoxidized oil was added. The mixture was heated to $100^{\circ} \mathrm{C}$. The reaction was carried out until the epoxy value of the whole mixture was $0 \mathrm{~mol} / 100 \mathrm{~g}$.

\section{Foam preparation}

The PUR foams were prepared by a free-rise method according to the formulations presented in the Table 1. The isocyanate index of RPUF was 110. The polyols were mixed with the additives (catalysts, surfactant and blowing agent) for $60 \mathrm{~s}$, and then isocyanate was added and the whole reaction mixture was stirred for another $6 \mathrm{~s}$. Afterwards, the mixture was quickly poured into a mold. The PUR foams obtained in this process were seasoned at room temperature for $24 \mathrm{~h}$ in order to finish crosslinking reactions, which take place in the obtained foams.

In the modified systems, the petrochemical polyol was replaced by respective biopolyols by 20,40 and $60 \%$ by mass. The systems were modified with the respective biopolyols P_1Hex and P_1.6Hex.

\section{Methods of testing}

\section{Biopolyol characterization}

The biopolyols obtained in the experiment were characterized by determining the iodine value in $\mathrm{gI}_{2} / 100 \mathrm{~g}$, acid value and the hydroxyl value, both in $\mathrm{mgKOH} / \mathrm{g}$.

The contents of hydroxyl and acid groups were determined according to the PN-93/C-89052/03 and PN-EN ISO 660:2009 standards, respectively. The designation of Iv was made using the Hanus method according to the PN-87/C-04281 standard.

The number $(\mathrm{Mn})$ and weight $(\mathrm{Mw})$ average molecular weights were determined by gel the permeation chroma- 
T a b l e 1. Formulation of PUR foams

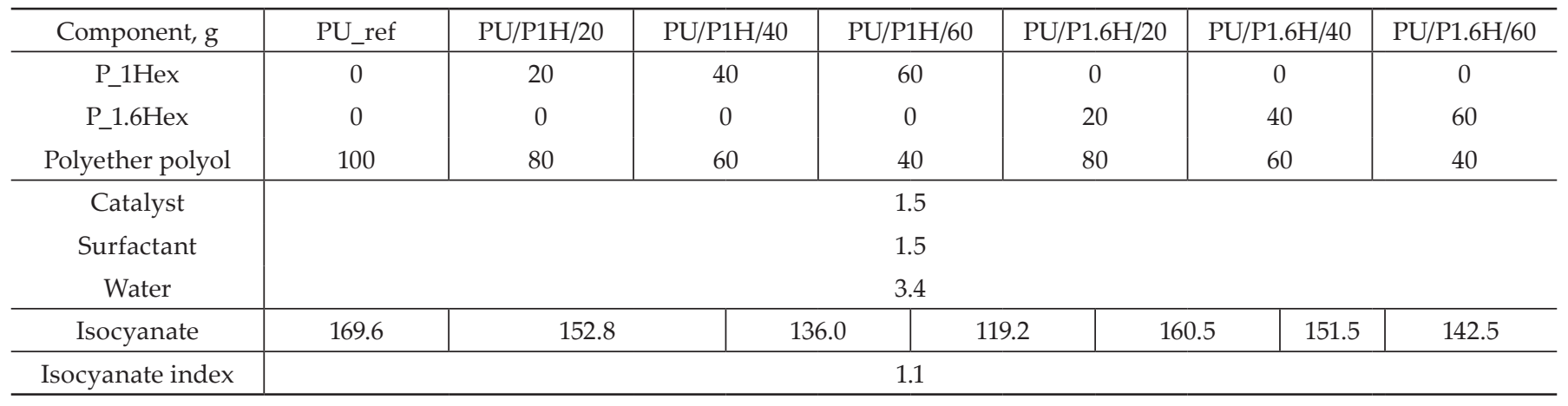

tography (GPC) analysis. GPC measurements were carried out using a Knauer chromatograph equipped with a PLgel MIXED-E column. Tetrahydrofuran was used as an eluent at a $0.8 \mathrm{~cm}^{3} / \mathrm{min}$ flow rate at room temperature. Dispersity (Đ) was calculated as the ratio of $M n$ and $M w$.

The density of the biopolyols was tested using calibrated densimeters (hydrometers) and a pycnometer with a capacity of $25 \mathrm{~cm}^{3}$. The test was performed at $20^{\circ} \mathrm{C}$ according to the ASTM D1217 standard.

The viscosity was determined using a rotational rheometer HAAKE MARS III (Thermo Scientific). The control rate mode was used in the plate-plate arrangement with the plates having a diameter of $20 \mathrm{~mm}$ and rotation speeds of 100 cycles/min.

The content of water in the biopolyols was analyzed according to PN-81/C- 04959 standard.

The characteristic bonds of the vegetable oils, epoxidized oils and biopolyols were analyzed by the means of a FTIR SPECTRUM 65 spectrometer (PerkinElmer) equipped with ATR Miracle with a ZnSe crystal.

\section{Foaming process and foam characterization}

The foaming process was analyzed using a FOAMAT device by Format-Messtechnik GmbH. The changes of temperature and dielectric polarization of reaction mixture during the foam growth were controlled. The software connected with FOAMAT calculates also other parameters e.g. characteristic time and pressure, times when parameter maxima are reached. Three samples of the same polyurethane system were used for each test.

The morphology of cells was analyzed using a scanning electron microscope (Hitachi S-4700). The anisotropy index was calculated as the ratio of the cell height and width.

The apparent density of the foams was measured as the ratio of mass to volume of a sample. The linear dimensions of the samples were $20 \times 20 \times 5\left(\mathrm{~cm}^{3}\right)$ and the measurement was carried out according to ISO 845 standard. The closed-cell content in the foams was measured by the pycnometer method according to ISO 4590 standard.

The thermal conductivity was determined using a Laser Comp Heat Flow Instrument Fox 200. The measurements were taken at an average temperature of $10^{\circ} \mathrm{C}$ (the cold plate temperature $0^{\circ} \mathrm{C}$ and the warm plate temperature $20^{\circ} \mathrm{C}$ were applied) according to ISO 8301 standard.

The brittleness of the examined materials was measured using the tumbling box technique in accordance with ASTM C421.

The compressive strength of the rigid foams was measured using a Zwick Z005 TH Allround-Line and results were registered by the program TEST Xpert 2. The measurements for each type of sample were taken in two directions with respect to the foam rise direction: parallel and perpendicular. The measurements were carried out using ISO 844:2014-11 standard.

\section{RESULTS AND DISCUSSION}

\section{Characterization of biopolyols based on rapeseed oil}

FT-IR spectra for the biopolyols, epoxidized oil and rapeseed oil are shown in Fig. 1. The disappearance of the alkene group stretching band at wave number $3007 \mathrm{~cm}^{-1}$ and the appearance of the epoxide groups stretching band at 824 and $840 \mathrm{~cm}^{-1}$ confirm the conversion of the rapeseed oil into an epoxidized biocomponent [24]. In order to obtain biopolyols with different functionality and chemical structure, two types of hexane hydroxyl derivatives (1-hexanol and 1,6-hexanediol) were used in the hydroxylation process of the epoxidized oils. The schemes of hypothetical chemical structures of the biopolyols are shown in Formulas (I) and (II).

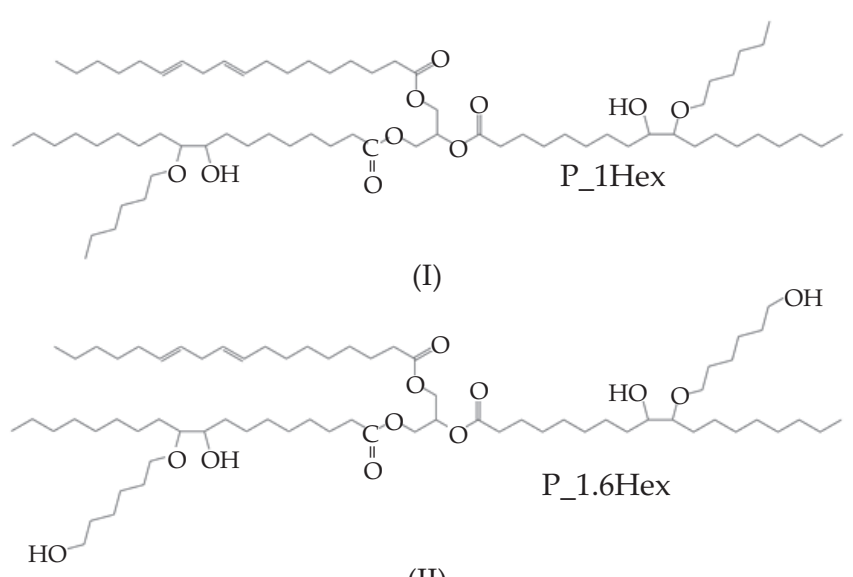

(II) 
a)

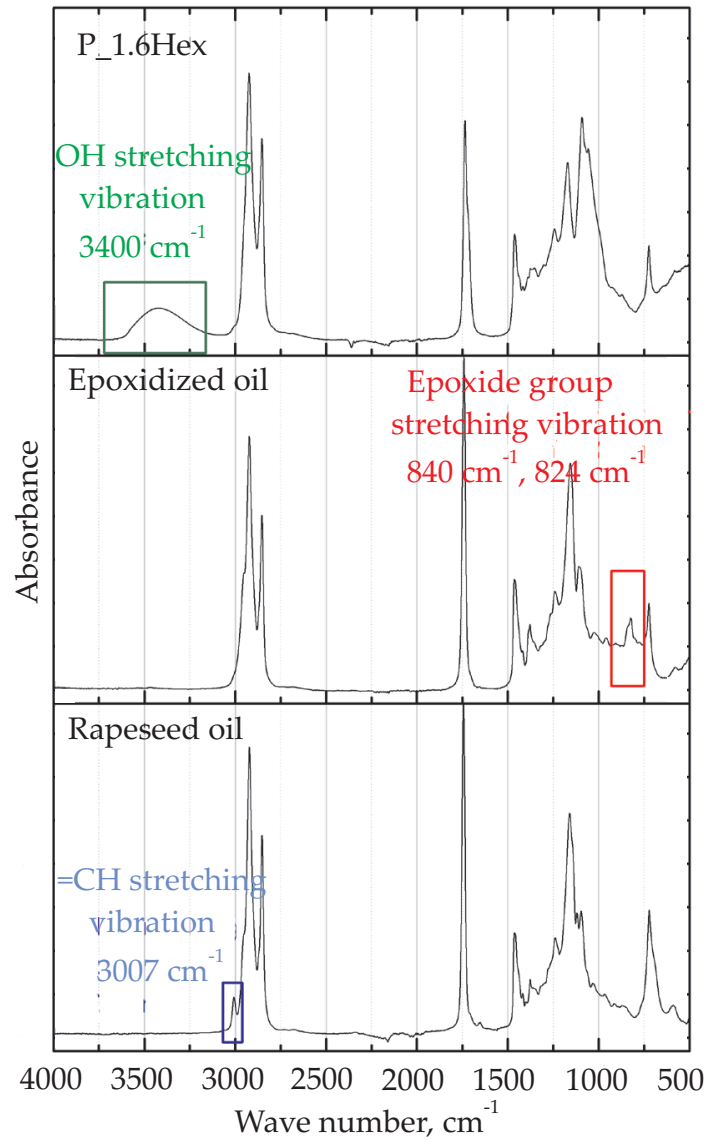

b)

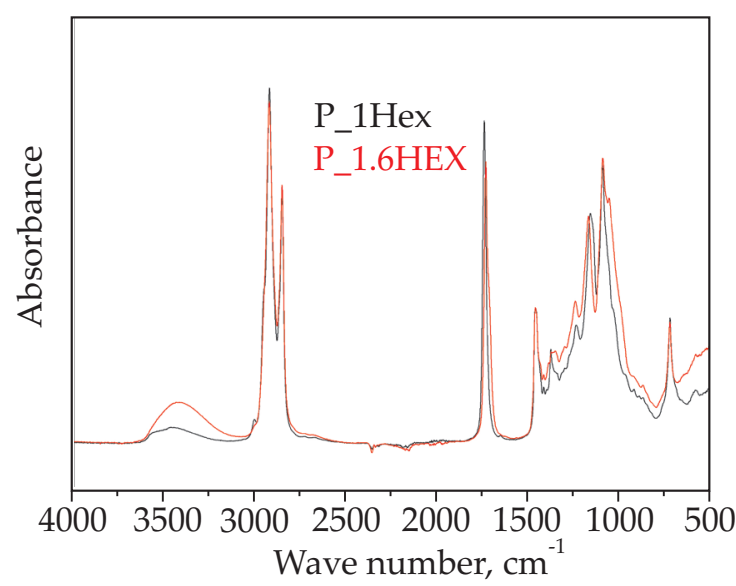

Fig. 1. FT-IR spectra of biocomponents: a) rapeseed oil, epoxidized oil and biopolyols with 1,6-hexanediol, b) biopolyols

The reaction of the epoxidized oil with 1-hexanol and 1,6-hexanediol was confirmed by the disappearance of the epoxide groups stretching band and the presence of broad hydroxyl groups stretching bands at 3200-3600 $\mathrm{cm}^{-1}$ as well as the values of hydroxyl numbers suitable for the reaction products (Table 2).

The reaction of the epoxidized rapeseed oil with 1-hexanol led to the formation of a biopolyol with secondary hydroxyl groups only. The hydroxylation process with 1,6-hexanediol allowed obtaining biocomponents containing a mixture of primary and secondary hydroxyl groups, as expected. The hydroxyl number of P_1.6Hex

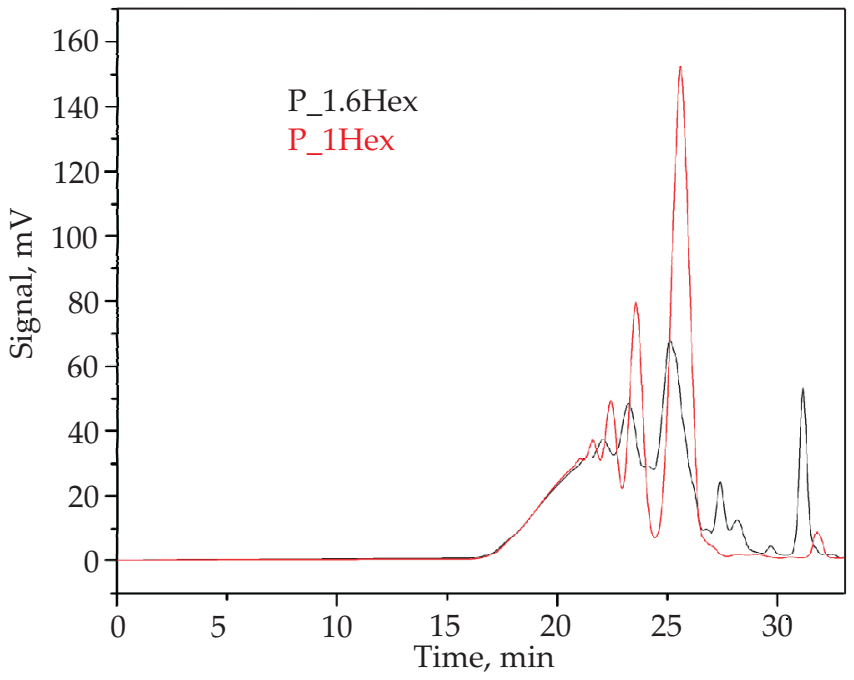

Fig. 2. GPC chromatogram of biopolyols

was more than twice as high as that of biopolyol P_1Hex (Table 2).

The functionality of the polyols was calculated based on the hydroxyl number and number average molecular weight, which was determined by GPC. The higher functionality of $\mathrm{P}_{-} 1.6 \mathrm{Hex}$ results from the use of a diol to open oxirane rings and a higher hydroxyl value for this polyol. Table 2 shows the average molecular weights for both biopolyols, $M w$ values in the range $2700-2900 \mathrm{~g} / \mathrm{mol}$ were obtained. These values are much higher than those reported in the literature [22], which is the result of oligomerization processes occurring during the opening of oxirane rings. This is also confirmed by the values of dispersity (Table 2). The higher dispersity of biopolyol P_1.6Hex was caused by the oligomerization and transesterification reactions that took place in this case (Fig. 2).

The theoretical hydroxyl value of biopolyol P_1Hex and P_1.6Hex are 114 and $320 \mathrm{mgKOH} / \mathrm{g}$, respectively. The measured hydroxyl values of the biopolyols were 104 and $250 \mathrm{mgKOH} / \mathrm{g}$, respectively. The lower hydroxyl values are a result of the oligomerization process. Furthermore, products from the transesterification process of the biopolyol P_1.6Hex can be observed in the GPC chromato-

T a b l e 2. Properties of biopolyols

\begin{tabular}{l|c|c}
\hline \multicolumn{1}{c|}{ Property } & P_1Hex & P_1.6Hex \\
\hline Hydroxyl value, $\mathrm{mgKOH} / \mathrm{g}$ & 104 & 250 \\
Acid value, $\mathrm{mgKOH} / \mathrm{g}$ & 1.38 & 4.05 \\
Iodine value, $\mathrm{gI}_{2} / \mathrm{100 \textrm {g }}$ & 58 & 25 \\
Density, $\mathrm{kg} / \mathrm{m}^{3}$ & 941 & 992 \\
Viscosity, mPa·s & 643 & 5128 \\
Water content, \% & 0.05 & 0.38 \\
Number average molecular weight, g/mol & 1442 & 978 \\
Weight average molecular weight, g/mol & 2792 & 2831 \\
Dispersity & 1.94 & 2.89 \\
Functionality & 2.67 & 4.36 \\
\hline
\end{tabular}


gram. It was the effect of use sulfuric acid as the catalyst during the opening oxirane rings.

The biopolyol with 1,6-hexanediol was characterized by a much lower hydroxyl value obtained in reaction than the theoretical one. In addition, it contained both primary and secondary groups. According to the literature, [3] primary hydroxyl groups are more reactive and can cause oxirane rings to open in epoxidized oil chains. This leads to oligomerization and the opening agent remains in the reaction mixture. The high water content of the biopolyol with 1,6-hexanediol $(0.38 \%)$ may be due to the condensation reactions taking place, a by-product of which is water.

The biopolyol with 1-hexanol contained only secondary groups that had less reactivity. It follows that the hydroxyl groups formed would not react with the oxirane rings, so their opening was limited. This is due to the difficult access of this group to the oxirane chain. What is more, there is no condensation reaction and the water content in the system was much lower than in biopolyol P_1.6Hex. The difference between the theoretical and the experimental hydroxyl number for this biopolyol was small.

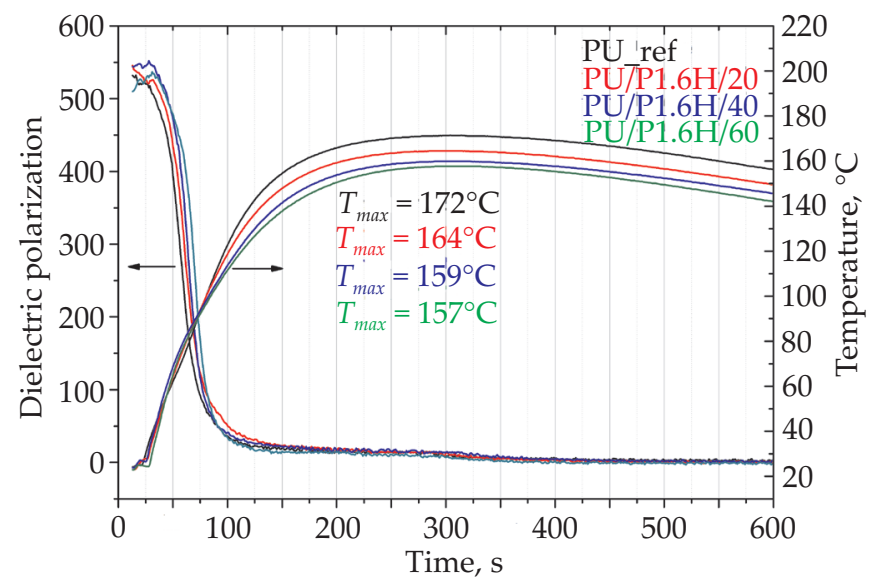

\section{Influence of biopolyols functionality on foaming process}

The foaming process is a very important step in the synthesis of porous PUR materials. It has a significant influence on creating the cell structure of PUR foams. An introduction of the biopolyols with different chemical structure and functionality to the reference PUR composition caused different changes in the reactivity of the modified systems. The analysis of the foaming process was done for the systems with the same contents of the catalyst. Figure 3 shows the changes of the dielectric polarization and temperature during the foaming process for the systems without biopolyol P_1.6Hex and different contents of this biopolyol. Increasing the amount of biopolyol P_1.6Hex in the PUR composition caused a decrease in its reactivity. It was confirmed especially by the decrease of the reaction mixture temperature.

The higher the amount of the biopolyol content in the PUR system, the lower the maximum temperature during foam growth was. The type of biopolyol has significant effect on the foaming process parameters. Biopolyol P_1.6Hex is more reactive than biopolyol P_1Hex. It



Fig. 3. Influence of biopolyols on dielectric polarization and temperature for PUR systems modified with: a) biopolyol $P_{-} 1.6 H e x$, b) $60 \mathrm{wt} \%$ biopolyols P_1Hex and P_1.6Hex

T a b l e 3. Parameters of cell structure of foams

\begin{tabular}{|c|c|c|c|c|}
\hline \multirow[b]{2}{*}{ Foam symbol } & \multicolumn{2}{|c|}{ Parallel direction } & \multicolumn{2}{|c|}{ Perpendicular direction } \\
\hline & Anisotropy index & $\begin{array}{l}\text { Cross section area } \cdot 10^{2} \\
\mathrm{~mm}^{2}\end{array}$ & Anisotropy index & $\begin{array}{c}\text { Cross section area } \cdot 10^{2} \\
\mathrm{~mm}^{2}\end{array}$ \\
\hline PU_ref & $1.34 \pm 0.17$ & $1.05 \pm 0.12$ & $1.19 \pm 0.13$ & $0.68 \pm 0.20$ \\
\hline PU/P1.6H/20 & $1.34 \pm 0.19$ & $0.74 \pm 0.09$ & $1.20 \pm 0.12$ & $0.47 \pm 0.04$ \\
\hline PU/P1.6H/40 & $1.51 \pm 0.25$ & $0.76 \pm 0.11$ & $1.19 \pm 0.11$ & $0.54 \pm 0.07$ \\
\hline PU/P1.6H/60 & $1.59 \pm 0.22$ & $0.88 \pm 0.08$ & $1.21 \pm 0.14$ & $0.42 \pm 0.06$ \\
\hline PU/P1H/20 & $1.33 \pm 0.18$ & $0.81 \pm 0.21$ & $1.18 \pm 0.13$ & $0.55 \pm 0.08$ \\
\hline PU/P1H/40 & $1.55 \pm 0.29$ & $1.02 \pm 0.26$ & $1.21 \pm 0.14$ & $0.55 \pm 0.05$ \\
\hline PU/P1H/60 & $1.56 \pm 0.28$ & $0.96 \pm 0.17$ & $1.21 \pm 0.14$ & $0.56 \pm 0.03$ \\
\hline
\end{tabular}


T a b l e 4. SEM microphotographs of foams

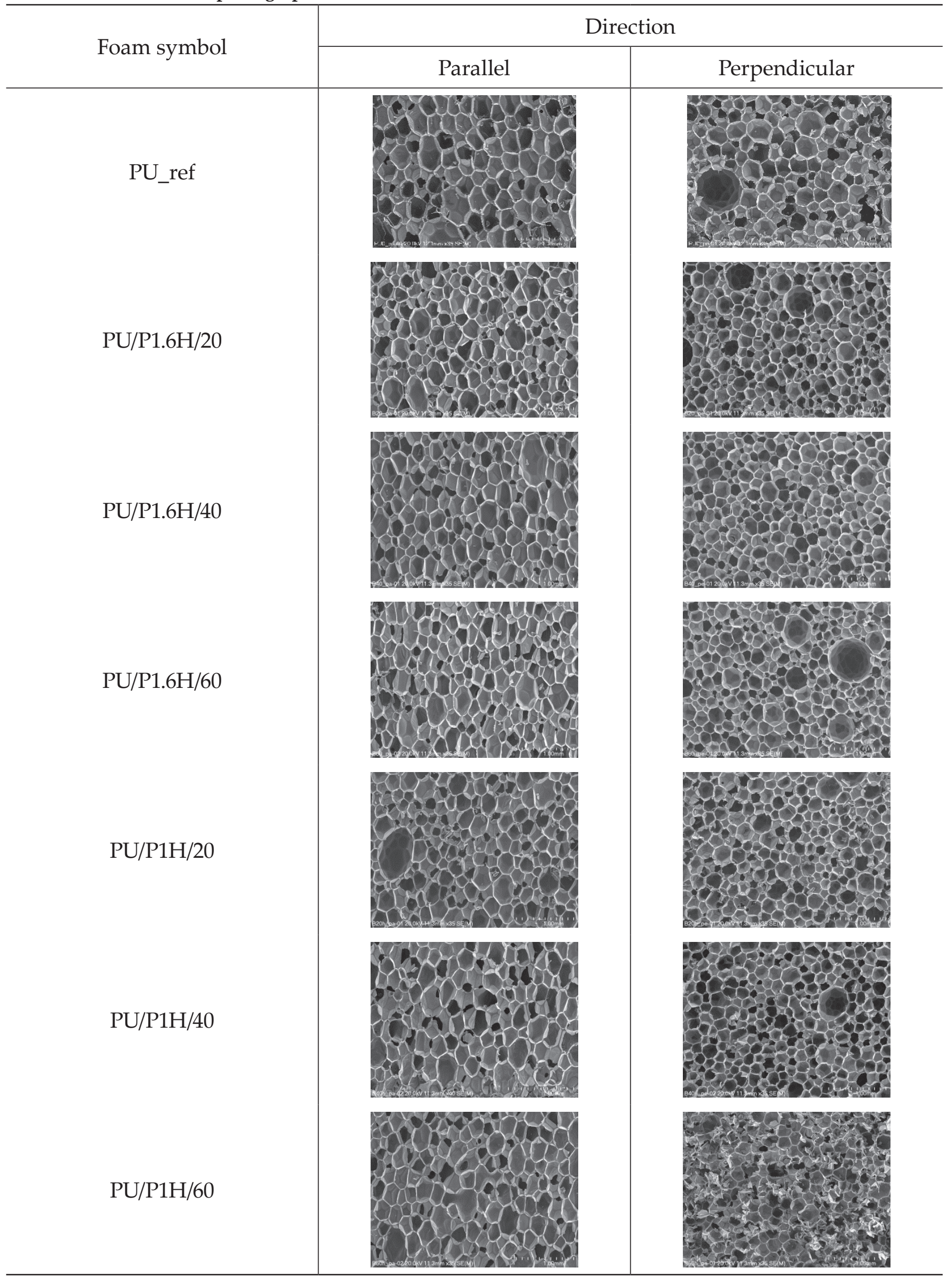


is confirmed by the changes of the temperature and dielectric polarization shown in Fig. 3b. The changes of the dielectric polarization and temperature during the foaming process for compared PUR systems modified with $60 \mathrm{wt} \%$ of the biopolyols have a little different character. The system with biopolyol P_1.6Hex is characterized by a higher reactivity comparing to the system modified with biopolyol P_1Hex, however the maximum temperature reached during the foaming process of the $\mathrm{PU} / \mathrm{P} 1.6 \mathrm{H} / 60$ system is by $c a .20^{\circ} \mathrm{C}$ lower than in the case of the reference system. The lowest reactivity and the lowest maximum temperature are found for system PU/ $\mathrm{P} 1 \mathrm{H} / 60$. The lower maximum temperature is an effect of the lower system reactivity.

A similar effect was obtained by Kurańska et al. [25]. In their work, a PUR system was modified by a rapeseed oil-based polyol in quantities 30, 50 and $70 \mathrm{wt} \%$. In their experiment, it was observed that an increase in the amount of the biopolyol in the PUR system reduced the reactivity. The lower maximum temperature was observed as an effect of the increasing biopolyol amount in the polyol premix.

\section{Influence of biopolyols functionality on cell structure of PUR foams}

The data related to the cell structure of the foams (anisotropy index and cross section area in parallel and perpendicular cross sections to the foam rise direction) are shown in Table 3 and the cell structure of the foams is presented in the SEM microphotographs included in Table 4.

The anisotropy index of cells in all the foams is higher in the parallel than in the perpendicular cross section. Generally, the modification of the PUR system with the biopolyols affected the anisotropy index causing elongation of cells in the foaming direction. The introduction of $40 \mathrm{wt} \%$ of both biopolyols into the PUR system resulted in a significant increase in the anisotropy index of cells in the parallel cross section to the foam rise direction only. The introduction of both biopolyols into the PUR system resulted in a decrease in the cell cross section area.
A higher average cross section area of cells in the parallel cross sections of the foams than in the perpendicular direction is caused by an elongation of cells in the free foam rise direction. The replacement of the petrochemical polyol with the biopolyols resulted in more fine cells in the modified foams. This was due to the fact that as the biopolyol content increased, the viscosity of the reaction mixture increased too [26].

The physical and mechanical properties of the PUR foams are shown in Table 5. Generally, the apparent density decreased when the amount of the biopolyols in the PUR system increased. However, the apparent density of foam PU/P1H/60 was a little higher than that of foam PU/ $\mathrm{P} 1 \mathrm{H} / 40$. This was due to the irregular cell structure and holes inside foam PU/P1H/60. Decreasing apparent density in the PUR foams modified with P_1.6Hex biopolyol can be caused by the changes of the total amount of water in the PUR premix. The water content in the P_1.6Hex biopolyol was a little higher than in the P_1Hex biopolyol, which could have an influence on the foaming process due to the reaction with isocyanate and generation of carbon dioxide. On the other hand, some changes of the apparent density of the PUR foams with the P_1Hex biopolyol are the results of its lower viscosity comparing to the P_1.6Hex biopolyol. Similar results of apparent density changes were observed in the work of Kurańska et al. [17]. In that case, a PUR system was modified using two types of biopolyols. When the amount of the biopolyols was increased in the PUR system, the apparent density of the rigid PUR foams decreased.

One of the important parameters for rigid PUR foams is thermal conductivity. Researchers are still working to obtain materials characterized by a low value of this parameter. Table 5 shows the thermal conductivity of the PUR foams used in the experiment. This parameter is in the range of $25.6-34.5[\mathrm{~mW} /(\mathrm{m} \cdot \mathrm{K})]$. An increase in the thermal conductivity coefficient was observed as an effect of increasing the amount of the P_1Hex biopolyol. It was associated with a decreasing apparent density of the modified foams and the presence of holes (defects) in the cell structure. In the case of the foams modified with the P_1.6Hex biopolyols, the decrease of the foam apparent

T a b l e 5. Physical-mechanical properties of PUR foams

\begin{tabular}{|c|c|c|c|c|c|c|c|}
\hline Property/Sample symbol & 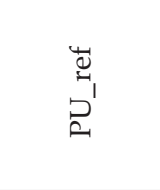 & 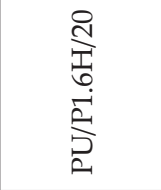 & 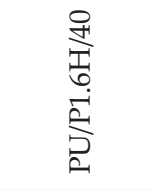 &  & 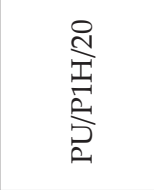 & 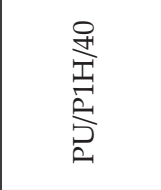 & 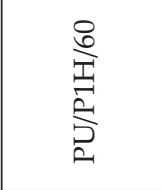 \\
\hline Apparent density, $\mathrm{kg} / \mathrm{m}^{3}$ & $40.6 \pm 0.2$ & $39.7 \pm 0.5$ & $38.7 \pm 0.2$ & $37.8 \pm 0.2$ & $38.0 \pm 1.6$ & $36.8 \pm 0.2$ & $37.2 \pm 0.9$ \\
\hline Content of closed cells, $\%$ & $85.2 \pm 1.3$ & $90.7 \pm 1.1$ & $94.2 \pm 0.5$ & $89.9 \pm 2.2$ & $85.0 \pm 3.0$ & $84.1 \pm 3.0$ & $84.1 \pm .0$ \\
\hline Thermal conductivity, $\mathrm{mW} /(\mathrm{m} \cdot \mathrm{K})$ & $25.69 \pm 0.04$ & $25.56 \pm 0.20$ & $25.66 \pm 0.21$ & $27.26 \pm 0.06$ & $29.22 \pm 0.22$ & $30.05 \pm 0.21$ & $34.45 \pm 0.30$ \\
\hline Brittleness, $\%$ & 3.8 & 3.6 & 4.0 & 3.1 & 10.9 & 7.7 & 3.2 \\
\hline Compressive strength - parallel, $\mathrm{kPa}$ & $280 \pm 11$ & $227 \pm 14$ & $257 \pm 12$ & $213 \pm 8$ & $189 \pm 8.77$ & $160 \pm 7.70$ & $\mathrm{nt}^{*}$ \\
\hline Compressive strength - perpendicular, $\mathrm{kPa}$ & $153 \pm 11$ & $141 \pm 4$ & $128 \pm 6$ & $96 \pm 5$ & $154 \pm 7.7$ & $112 \pm 1.8$ & $\mathrm{nt}^{*}$ \\
\hline
\end{tabular}

* - not tested due to defects in cell structures 
density was balanced by a a higher closed cell content for the samples PU/P1.6H/20 and PU/P1.6H/40. The highest value of this parameter for the $\mathrm{PU} / \mathrm{P} 1 \mathrm{H} / 60$ foam resulted from the disturbance of the cell structure and a lower content of closed cells. Similar results were obtained in the work [27]. Increasing the amount of a soy-based biopolyol in a PUR system caused increasing thermal conductivity of modified foams.

Due to the anisotropic cell structure of the PUR foams used in our study, the compressive strength was measured in parallel and perpendicular directions to the foam rise direction. The results (Table 5) show that increasing the amount of the biopolyols led to a decrease of the foam compressive strength. The lower value of the compressive strength was observed for the PUR systems with P_1Hex than P_16Hex biopolyol compared to the reference foam. The reduced compressive strength is an effect of the decreasing foam apparent density as well as crosslinking density of the PUR foams with the biopolyol of lower functionality (P_1Hex). Furthermore, a higher compressive strength measured parallel to the foam rise direction was due to the elongation of cells in this direction. The lower value of the compressive strength was observed for the PUR systems with P_1Hex than P_1.6Hex. Similar effects of the use of biobased polyols are reported in the works $[1,28]$. The brittleness of all the PUR foams shown in Table 5 is on a similar level. The values of this property for the foams PU/P1H/20 and PU/P1H/40 were unexpectedly a little higher. However, increasing the amount of the P_1Hex biopolyol in the PUR system allowed reducing the foam brittleness due to the plasticizing effect of dangling chains from the biopolyol as well as a decrease of the crosslinking density of the foams (low functionality of $\mathrm{P}_{-} 1 \mathrm{Hex}$ biopolyol).

\section{CONCLUSIONS}

The results presented in this work confirm that it is possible to produce good quality rigid foams by replacing the petrochemical polyol in a polyurethane system with biopolyols up to $40 \%$ by mass and maintaining the same level of catalyst and surfactant. However, the chemical structure and functionality of the biopolyols has a significant effect on the foaming process and the properties of the resultant rigid polyurethane foams.

The polyurethane systems modified with the biopolyol of higher functionality were characterized by higher reactivity than the systems with the biopolyol of lower functionality. This is due to the fact that the biopolyol with 1,6-hexanediol contained primary $\mathrm{OH}$ groups, which are much more reactive than secondary $\mathrm{OH}$ groups.

As the biopolyol content in the polyurethane systems increased, the apparent density of the foams decreased. Unfortunately, the opposite effect was observed in the case of thermal conductivity values in the case of the foams modified with the biopolyol with low functionality.
A significant decrease of the compressive strength of the foams modified with the biopolyol of lower functionality was associated with a lower crosslinking density of the modified polyurethane foams as well as their lower apparent density. The compressive strength values of the foams modified with both biopolyols up to $40 \mathrm{wt} \%$ are sufficient to maintain dimensional stability.

\section{ACKNOWLEDGMENTS}

The authors gratefully acknowledge the support of this work by research grant from National Center for Research and Development in Poland under contract no. M-ERA. NET2/2017/2/2018 "Development of Biobased Cryogenic Insulation Modified with Nanocrystalline Cellulose (Bio4Cryo)".

The authors are grateful to Momentive Performance Materials Inc., for supplying surfactants.

The authors are grateful to Biesterfeld Spezialchemie $\mathrm{GmbH}$ for supplying catalyst.

\section{REFERENCES}

[1] Zieleniewska M., Leszczyński M.K., Kurańska M. et al.: Industrial Crops and Products 2015, 74, 887. https://doi.org/10.1016/j.indcrop.2015.05.081

[2] D'Souza J., George B., Camargo R., Yan N.: Industrial Crops and Products 2015, 76, 1.

https://doi.org/10.1016/j.indcrop.2015.06.037

[3] Prociak A., Kurańska M., Malewska E.: Polimery 2017, 62, 353.

https://doi.org/10.14314/polimery.2017.353

[4] Prociak A., Malewska E., Kurańska M. et al.: Industrial Crops and Products 2018, 115, 69.

https://doi.org/10.1016/j.indcrop.2018.02.008

[5] Kirpluks M., Kalnbunde D., Benes H., Cabulis U.: Industrial Crops and Products 2018, 122, 627. https://doi.org/10.1016/j.indcrop.2018.06.040

[6] Ghasemlou M., Daver F., Ivanova E.P., Adhikari B.: Industrial Crops and Products 2019, 142, 1. https://doi.org/10.1016/j.indcrop.2019.111841

[7] Gaidukova G., Ivdre A., Fridrihsone A. et al.: Industrial Crops and Products 2017, 102, 133. https://doi.org/10.1016/j.indcrop.2017.03.024

[8] Tan S., Abraham T., Ference D., MacOsko C.W.: Polymer 2011, 52, 2840.

https://doi.org/10.1016/j.polymer.2011.04.040

[9] Oh J.H., Bae J.H., Kim J.H. et al.: Polymer Testing 2019, 80, 106093.

https://doi.org/10.1016/j.polymertesting.2019.106093

[10] Linul E., Marşavina L., Vălean C., Bănică R.: Engineering Fracture Mechanics Journal 2020, 225, 106274.

https://doi.org/10.1016/j.engfracmech.2018.12.007

[11] Kurańska M., Prociak A., Mikelis K., Cabulis U.: Composites Science and Technology 2013, 75, 70. https://doi.org/10.1016/j.compscitech.2012.11.014

[12] Prociak A., Rojek P., Pawlik H.: Journal of Cellular Plastics 2012, 48, 489. 
https://doi.org/10.1177/0021955X12446210

[13] Paciorek-Sadowska J., Borowicz M., Czupryński B. et al.: Industrial Crops and Products 2018, 126, 208. https://doi.org/10.1016/j.indcrop.2018.10.019

[14] Prociak A.: Polimery 2008, 53, 195. http://dx.doi.org/10.14314/polimery.2008.196

[15] Venkatesh D., Jaisankar V.: Materials Today: Proceedings 2019, 14, 482. https://doi.org/10.1016/j.matpr.2019.04.171

[16] Ji D., Fang Z., He W. et al.: Industrial Crops and Products 2015, 74, 76 . https://doi.org/10.1016/j.indcrop.2015.04.041

[17] Kurańska M., Pinto J.A., Salach K. et al.: Industial Crops and Products 2019, 143, 111882. https://doi.org/10.1016/j.indcrop.2019.111882

[18] Allauddin S., Somisetti V., Ravinder T. et al.: Industial Crops and Products 2016, 85, 361. https://doi.org/10.1016/j.indcrop.2015.12.087

[19] Gama N.V., Ferreira A., Barros-Timmons A.: Materials 2018, 11, 10. https://doi.org/10.3390/ma11101841

[20] Lligadas G., Ronda J.C., Galiá M., Cádiz V.: Biomacromolecules 2010, 11, 2825. https://doi.org/10.1021/bm100839x
[21] Li H., Feng S., Yuan Z. et al.: Industial Crops and Products 2017, 109, 426. https://doi.org/10.1016/j.indcrop.2017.08.060

[22] Nohra B., Candy L., Blanco J. F. et al.: Macromolecules 2013, 46, 3771. https://doi.org/10.1021/ma400197c

[23] Prociak A., Kurańska M., Cabulis U. et al.: Industial Crops and Products 2018, 120, 262. https://doi.org/10.1016/j.indcrop.2018.04.046

[24] Tuan Ismail T.N.M., Ibrahim N.A., Mohd Noor M.A. et al.: European Journal of Lipid Science and Technology 2018, 120, 1700354. https://doi.org/10.1002/ejlt.201700354

[25] Kurańska M., Prociak A.: Industial Crops and Products 2016, 89, 182. https://doi.org/10.1016/j.indcrop.2016.05.016

[26] Zhang C., Kessler M.R.: ACS Sustainable Chemistry \& Engineering 2015, 3, 743. https://doi.org/10.1021/acssuschemeng.5b00049

[27] Dhaliwal G.S., Anandan S., Chandrashekhara K. et al.: European Polymer Journal 2018, 107, 105. https://doi.org/10.1016/j.eurpolymj.2018.08.001

[28] Hu S., Li Y.: Bioresource Technology 2014, 161, 410. https://doi.org/10.1016/j.biortech.2014.03.072

Received 25 V 2020. 